\title{
Effects of Professional Skills and Auditor Competence on Audit Quality in Inspectorate Southeast Sulawesi Province
}

Submitted 25/11/20, $1^{\text {st }}$ revision 28/01/21, $2^{\text {nd }}$ revision 19/02/201, accepted 20/03/21

\author{
Mulyati Akib ${ }^{1}$, La Ode Anto ${ }^{2}$
}

\begin{abstract}
:
Purpose: This study aimed to determine the Effect of Professional Skills and Auditor Competence on Audit Quality in the Provincial Inspectorate of Southeast Sulawesi.

Design/Methodology/Approach: The sample was 31 auditors of the Southeast Sulawesi Provincial Inspectorate attained using the saturation sampling method. The data collected using a questionnaire.

Finding: Initially, the questionnaire was tested for validity and reliability, and the test results showed that all instruments were valid and reliable. The test assumptions included autocorrelation test, heteroscedasticity test, normality test, and multicollinearity test. Data analysis employed multiple linear analysis methods.

Practical Implication: This implies that to carry out a good audit, the auditor at the Southeast Sulawesi Provincial Inspectorate requires knowledge obtained from education and courses and training to produce high-quality audit results.

Original/Value: The results of this study indicated that Professional Capability partially has a positive and significant effect on Audit Quality, Auditor Competency has a positive and significant effect on Audit Quality, and Professional Capability and Auditor Competency simultaneously has a significant effect on Quality Audit.
\end{abstract}

Keywords: Professional skills, auditor competence, audit quality.

JEL classification: L26, O29.

Paper Type: Research paper.

${ }^{1}$ Departement Accounting, Economi and Bussiness Faculty, Halu Oleo University, Indonesia, mulyatiakib@yahoo.co.id

${ }^{2}$ Departement Accounting, Economi and Bussiness Faculty, Halu Oleo University, Indonesia. 


\section{Introduction}

Regional Governments are mandated to regulate and manage their own government affairs according to the principle of autonomy and co-administration by Law Number 23 of 2014 regarding Regional Governments and Law Number 33 of 2004 concerning Financial Balance between Central and Regional Governments instead of Laws Number 25 of 1999.

Generally, the purposes of implementing regional autonomy are to increase regional independence, improve transparency and public accountability for regional financial management, increase government responsiveness to public needs, increase public participation in regional development, improve efficiency and effectiveness of financial management and public services and encourage democratization in the regions (Mahmudi, 2015). Each region must hold accounting and prepare financial reports from the region concerned, such as budget realization reports, financial position reports, notes to financial statements. The government must take precautions in making financial reports to avoid raising a question that causes people to be less confident in the financial statements that the government has made.

Provincial Inspectorate and Regency/City Inspectorate is a supervisory agency within the regional government environment, both at the provincial, district, or city level, which holds a significant role in the progress and success in performing the government to achieve the predetermined goals and objectives.

The Southeast Sulawesi Provincial Inspectorate, in carrying out its duties and responsibilities, is divided into four Regional Assistant Assistors (IRBAN) consisting of auditors and the Local Government Affairs Supervisory Officer (P2UPD). In exercising their main tasks and functions, the Southeast Sulawesi provincial Inspectorates regularly inspect the Regional Government Work Unit within the Southeast Sulawesi Provincial Government. The Provincial Inspectorate's role is to assist the Governor in supervising government administration so that it can run efficiently and effectively. Therefore, the Inspectorate is required to produce good audio quality.

The phenomenon that occurred in various findings of the Southeast Sulawesi Inspectorate is due to BPK RI Southeast Sulawesi Representative's finding from the follow-up monitoring of the inspection results. The BPK RI Southeast Sulawesi Representative assessment process includes: (1) Conformity to Financial Statements, (2) Internal Control Systems and (3) Compliance with laws and regulations. The Indications that there is a limitation of the Southeast Sulawesi Provincial Inspectorate auditor in finding or exposing violations could have been greater. The existence of quite high differences in findings indicates that the quality of auditors of the Southeast Sulawesi Provincial Inspectorate is still considered not optimal as an internal auditor, especially since both institutions use the same audit 
standards, code of ethics, and accounting standards in carrying out their duties and functions as auditors. The aims of this study were to:

a) find out and analyze the effect of auditor professional skills on audit quality at the Southeast Sulawesi Provincial Inspectorate,

b) know and analyze the effect of auditor competence on audit quality at the Southeast Sulawesi Provincial Inspectorate,

c) know and analyze the influence of professional skills and competence auditor of audit quality at the Southeast Sulawesi Provincial Inspectorate.

\section{Theorical Foundation and Methodology}

Agoes (2017) defines auditing as a process to objectively obtain and evaluate evidence about assertions on economic activities and events to ensure the level of interrelation between these assertions, established criteria, and communicate the results to related parties. Professional skills are an important thing that every public accountant must apply in carrying out their professional work to achieve adequate audit quality. Professional skills involve two aspects, professional skepticism, and adequate beliefs. The public trusts the financial statements if the auditor has used his professional skepticism in the audit process.

Professional skills are important things that each auditor must apply in carrying out their professional work to achieve adequate audit quality. Professional skills involve two aspects, namely professional skepticism, and adequate beliefs. The public trusts the financial statements if the auditor has used his professional skepticism in the audit process. Accuracy requires auditors to be aware of significant risks. With a caring attitude, the auditor will expose various kinds of fraud in presenting financial statements more easily and quickly. Thus, in evaluating audit evidence, auditors are required to have adequate confidence (Singgih, 2010).

Data collection methods in this study used interviews, questionnaires, and literature studies. The interview is a technique of collecting data by holding questions and answers or direct interviews with authorized parties to collect data on Professional Skills, Competence, and Audit Quality in the Southeast Sulawesi Provincial Inspectorate. The autocorrelation test in this study was conducted to test a linear regression modal whether there is a correlation between residuals (confounding errors) from one period to another; a good regression model is free from autocorrelation or serial correlation. The autocorrelation test in this study was carried out using the Durbin Watson test.

\section{Results and Discussion}

\subsection{Results}


Description of the research variable aimed to interpret the frequency distribution of respondents' answers. The respondents' answers were categorized into five categories using a Likert scale. In giving the meaning of empirical assessment, this research variable adopted the weighting principle proposed by Solimun et al. (2017).

a) Variable Professional Skills (X1): For professional proficiency variables, the highest average answer was the skepticism indicator (X1.1), with an average of 4.39 or in the excellent category. For statements on adequate confidence indicators (X1.2) were in the good category with an average of 4.30 .

b) Competency Variables (X2): According to respondents ' responses, indicators of general knowledge (X2.2) were included in the good category with a mean value of 4.52. Experience indicators (X2.4), according to respondents' responses, were included in the good category with a mean value of 4.50. According to respondents ' responses, personal quality indicators (X2.1) were included in the good category with a mean value of 4.47. According to respondents ' responses, indicators of special expertise (X2.3) were included in the good category with a mean value of 4.42.

c) Audit Quality Variable (Y): According to respondents ' perceptions, indicators of the principle of prudence (Y1.5) were in the good category with an average value of 4.30. According to the respondents ' perception, the indicator of misstatement detection (Y1.1) was relatively good, with an average value of 4.23 . According to respondents ' perceptions, compliance indicators with SOP (Y1.3) were good, with an average value of 4.23. According to respondents ' perceptions, audit risk indicators (Y1.4) was good, with an average value of 4.09. According to respondents perceptions, the indicator of conformity with SPAP (Y1.2) was good, with an average value of 4.02 .

\subsection{Discussion}

Also, the value of the probability of professional skills is 0.006 and smaller than 0.05 , indicating professional skills have a significant effect on audit quality. These results accepted the first hypothesis (H1) in this study that professional skills positively and significantly affect audit quality. Significant effect means the better the professional skills of an auditor in doing his work, the better the quality of the resulting audit. Based on respondents' responses, it shows that skepticism is the most dominant in the professional skills variable compared to other indicators. This can be seen from the average questionnaire answers to this indicator were in a good category.

Auditors who developed professional skills, in this case, have a skeptical attitude like every time there is a suspicious transaction, and they always question and critically evaluate audit evidence, it will produce a good quality of audit results. At 
the same time, other indicators contribute to the professional skill variable, which is adequate confidence. Auditors who have professional skills must have sufficient confidence in the audit evidence to produce good audit results. When the auditor wants to produce a good quality audit report, the auditor must apply professional skills to his audit assignments. This study is in line with a study by Faturachman (2015) and (Biantong 2016). (Faturachman, 2015) showed that auditor's professional due care has a significant positive effect on audit quality. Biantong (2016) explains that due professional care has a significant positive effect on audit quality. In contrast, the present study is not in line with the results of a study by (Saripudin, 2012) which stated that professional skills do not affect audit quality.

An auditor who always applies professional skills in every audit he conducts will often reject certain information unless the auditor finds evidence that the information is valid. The use of professional skills in each audit is not enough to produce good quality audit results. The application of professional skills must also be supported by adequate competence from the auditor. Auditors who have sufficient competence, including general knowledge, experience, and courses and training, will be able to work with the team, have a great curiosity, broad-minded and able to make audit reports and present properly so that the auditor will be able to detect fraud in financial statements and provide recommendations to correct and reduce the level of errors that have occurred.

\section{Conclusion and Suggestions}

This study's conclusions are: 1) Professional skills have a significant effect on audit quality. 2) Auditor competence has a significant effect on audit quality. 3) Professional skills and auditor competencies have a significant effect on audit quality.

Some suggestions submitted by the authors based on the results of the study are: 1) The Southeast Sulawesi Provincial Inspectorate Auditor must maintain and enhance the use of professional skills and competence of auditors in each audit. 2) For further researchers to add new independent variables, such as accountability, expertise, independence, work stress, and auditor experience, obtain better study results.

\section{References:}

Abdul, H. 2015. Auditing. Basics of Financial Statements, 1. UPP STIM YKPN: Yogyakarta.

Agoes, S. 2017. Auditing: Practical Guidelines for Accountant Examination by Public Accountants, 1. Jakarta: Salemba.

Akdon Ridwan. 2008. Application of Statistics and Research Methods for Administration \& Management. Bandung: Dewa Ruchi. 
Ramlah, S., Syah, A., Dara, M.A. 2007. Effect of Competence and Independence on Audit Quality with Auditor Ethics as Moderation Variables. Accounting National Symposium X.

Al Hara, M.M. 2018. The Influence of Auditor's Competence, Professional Skills, Independence, and Experience on Audit Quality (Empirical Study of Public Accounting Firms in Surakarta and Yogyakarta). Essay. Surakarta State Islamic Institute.

Arens, A.A, Randal, J.E, Mark, S.B. 2013. Auditing and Assurance Services: An Integrated Approach, 13th Edition. Pearson, Prentice Hall Inc.

Badjuri, A. 2011. Factors Affecting the Quality of the Independent Auditor's Audit at a Public Accounting Firm (KAP) in Central Java. Financial and Banking Dynamics, 3(2), 182-197.

Bastian, I. 2014. Public Sector Management Control Systems. Jakarta: Four Salemba.

Biantong, E. 2016. The Influence of Work Experience, Independence, and Auditor Due Professional Care on Audit Quality (Empirical Study at BPK RI Representative of South Sulawesi Province). Faculty of Economics and Business, Hasanuddin University, South Sulawesi.

State Audit Board of the Republic of Indonesia. 2017. BPK-RI Regulation No. 1 concerning State Financial Audit Standards (SPKN).

Christiawan, Y.J. 2002. Competence and independence of public accountants: Reflections on Empirical Research Results. Journal of Accounting and Finance, 4, 79-92.

Deis, D.R., Giroux, G.A. 1992. Determinants of Audit Quality in the Public Sector. Accounting Review.

Suhayati, E., Rahayu, S.K. 2010. Auditing, Basic Concepts and Guidelines for Public Accountant Examination. Yogyakarta: Graha Science.

Faturachman, S. 2015. The Influence of Due Professional Care Auditors on Audit Quality in Public Accounting Firms in Bandung. Essay. Bandung: Indonesian Education University.

Ghozali, I. 2011. Application of Multivariate Analysis with the IBM SPSS 23 program. Semarang: Diponegoro University Publisher Agency.

Harsanti, P. 2014. The Influence of Auditor's Competence, Independence, and

Professionalism on Audit Quality. Empirical Study at Public Accounting Firms in Semarang, 7(1).

Haryono, J. 2001. Auditing. Yogyakarta: STIE YKPN.

Hayes, A.S. 2012. Principles of Auditing an Indtroduction to International Standards on Auditing. Prentice Hall.

Ichwanty, A. 2015. The Effect of Competence, Independence, Due Professional Care, Accountability, and Ethics on Audit Quality, Empirical Study of Public Accountant Auditors in Riau Province and Riau Islands. Jom FEKON, 2.2.

Indonesian Institute of Accountants. 2012. Financial Accounting Standards. PSAK. Fourth Printing, Book One, Jakarta: Salemba Empat Publisher.

Indonesian Accountants Association (IAI). 2011. Professional Standards for Public Accountants. Jakarta: Salemba Empat.

Indriantoro, B.S. 2009. Business Research Methodology for Accounting and Management, First Edition. Yogyakarta: BPFE Yogyakarta.

Konrath, L.F. 2002. Auditing Concepts and Application, A Risk-Analysis Approach, 5th Ed. West Publishing Company.

Consortium of Internal Audit Professional Organizations. 2004. Internal Audit Professional Standards. Jakarta: Four Salemba. 
Mahmudi. 2015. Public Sector Performance Management, Third Edition. UPP STIM YKPN, Yogyakarta.

Marbun. 2015. The Influence of Competence, Independence, Professionalism, Work

Experience and Organizational Commitment on Audit Quality. Jom FEKON, 2(2).

Mardiasmo. 2009. Public Sector Accounting, 4th Edition. Yogyakarta: Publisher Andi.

Mulyadi. 2014. Auditing. Book Two. Sixth Edition. Jakarta: Four Salemba.

Minister of Home Affairs Regulation Number 2. 2011. The Second Amendment to the

Regulation of the Minister of Home Affairs Number 13 of 2006. Concerning

Guidelines for Regional Financial Management.

Regulation of the Minister of Home Affairs No.64. 2007. Technical Guidelines for the

Organization and Work Procedures of Provincial Inspectorates.

Regulation of the State Minister for State Apparatus Empowerment Number: PER / 05 /

M.PAN/03/2008 concerning Auditing Standards for Government Internal

Supervisory Apparatus.

Government Regulation Number 60. 2008. Government Internal Control Systems.

Government Regulation Number 79. 2005. Government Accounting Standards.

Regulation of the Republic of Indonesia, Government Regulation Number 79. 2005.

Guidance and Supervision of Local Government Administration.

Pertiwi, Nastia Putri. 2013. The Effect of Competence, Independence and Professionalism on Audit Quality (Empirical Study in Public Accounting Firms in Sumatra). Journal of Economics, 21(2). Riau Universit.

Rai, G.N. 2008. Public Sector Performance Audit; Concepts, Practices, Case Studies. Jakarta: Four Salemba.

Saripudin. 2012. The Effect of Independence, Experience, Due Professional Care and Accountability on Audit Quality (Survey of Public Accountant Firm Auditors in Jambi and Palembang). Binar Accounting E-Journal.

Singgih, E.M., Bawono, I.R. 2010. The Influence of Independence, Experience, Due

Professional Care and Accountability for Audit Quality. 12th National Symposium on Accounting, 1-24.

Sugiyono. 2017. Quantitative, Qualitative, and R \& D Research Methods. Bandung: Alfabeta.

Sujarweni, W. 2015. SPSS for Research. Yogyakarta: New Library Press.

Sukriah, I.A., Biana, A.I. 2009. The Influence of Work Experience, Independence, Objectivity, Integrity, and Competence on the Quality of Audit Results. Jakarta: Alfabeta.

Sunyoto, Danang. 2013. Theory, Questionnaires, and Data Analysis for Marketing and Consumer Behavior. Yogyakarta: Graha Science.

Theodorus, M.T. 2015. Contemporary Auditing (International Standards on Auditing). Jakarta: Four Salemba.

Tjun, L.T. et al. 2012. The Effect of Auditor Competence and Independence on Audit Quality. Journal of Accounting, 4(1).

Law Number 33 of 2004 concerning financial balance between the central government and regional governments.

Wibowo. 2014. Behavior in Organizations. Issues 1-2. Jakarta: Rajawali Press.

Wiratama, W.J., Budiartha. 2015. Effect of Independence, Work Experience, Due

Professional Care and Accountability on Audit Quality. Udayana University

Accounting E-journal, 1.

Wooten, T.C. 2003. Research About Audit Quality. The CPA Journal. 